\title{
Social Influence and Safe Behavior in Manufacturing
}

\author{
Hald, Kim Sundtoft
}

Document Version

Accepted author manuscript

Published in:

Safety Science

DOI:

10.1016/j.ssci.2018.05.008

Publication date:

2018

License

CC BY-NC-ND

Citation for published version (APA):

Hald, K. S. (2018). Social Influence and Safe Behavior in Manufacturing. Safety Science, 109, 1-11.

https://doi.org/10.1016/j.ssci.2018.05.008

Link to publication in CBS Research Portal

\section{General rights}

Copyright and moral rights for the publications made accessible in the public portal are retained by the authors and/or other copyright owners and it is a condition of accessing publications that users recognise and abide by the legal requirements associated with these rights.

Take down policy

If you believe that this document breaches copyright please contact us (research.lib@cbs.dk) providing details, and we will remove access to the work immediately and investigate your claim. 


\title{
Social Influence and Safe Behavior in Manufacturing Kim Sundtoft Hald
}

\author{
Journal article (Accepted manuscript*)
}

\section{Please cite this article as:}

Hald, K. S. (2018). Social Influence and Safe Behavior in Manufacturing. Safety Science, 109, 1-11. https://doi.org/10.1016/j.ssci.2018.05.008

DOl: 10.1016/j.ssci.2018.05.008

* This version of the article has been accepted for publication and undergone full peer review but has not been through the copyediting, typesetting, pagination and proofreading process, which may lead to differences between this version and the publisher's final version AKA Version of Record.

Uploaded to CBS Research Portal: July 2019

(C) 2019. This manuscript version is made available under the CL-BY-NC-ND 4.0 license http://creativecommons.org/licenses/by-nc-nd/4.0/ 


\title{
Social influence and safe behavior in manufacturing
}

\author{
Kim Sundtoft Hald \\ Professor \\ Copenhagen Business School, Department of Operations Management \\ Solbjerg Plads 3, 2000 Frederiksberg, Denmark \\ Tel: +4523722303 \\ E-mail: ksh.om@,cbs.dk
}

\begin{abstract}
This research presents a model designed to explore the cognitive and social mechanisms that mediate the relationship between organizational safety climate and safety behaviors. Specifically the presented research demonstrates the usefulness of Sussmann and Vecchio (1982) social influence interpretation of worker motivation to understand safety motivation. Survey data was collected from 428 employees in seven factories within the electronics industry in China. The data were analyzed using structural modelling. The results suggest that factory workers with more knowledge about the products, organization, goals/objectives and customers of the factory engage in safer work behavior. From social influence theory this may be understood as a process of identification, where factory workers through their involvement and increased knowledge of the factory are socially committed and influenced to work safely via their increased attractiveness of membership in the organization. This complements existing research and shows how other types of knowledge not directly related to safety knowledge may be important for improving safe work behavior. Another finding from the presented research indicate that the total effects of a factory workers experience with safety and health problems seems to affect safe work behavior negatively, and that this is caused by a decrease in confidence and abilities to work safely. In relation to practical implications the present study demonstrate how manufacturing managers can purposely adopt value related; identity related and utility related interpersonal influence processes to influence and improve factory workers commitment to work safely.
\end{abstract}

Keywords: Safety climate; Safety motivation; Safety behavior; Social influence theory

Paper type: Research paper 


\section{Introduction}

The management of workplace safety has major economic and social consequences (Hedelund et al., 2016). When manufacturing managers makes decision related to workplace safety this affects the level of insurance costs as well as accident prevention and incurrence costs (Loeppke et al., 2007). Also the value of the firm, its brand and the productivity of the factory is affected by such decisions (Fernandez-Muniz et al., 2009). In respect to social implications, manufactory managers' decisions related to workplace safety affects the frequency of factory worker accidents as well as workplace incurred illness. More accidents may in turn lead to social decay of workers and to manufacturing processes caught in vicious cycle dominated by a deteriorating safety climate and safety performance. The ability to manage occupational health and safety in manufacturing is therefore increasingly important to society, to operations management and to the supply chain.

Workplace safety has been explored extensively across disciplines (Eid et al., 2012; Fan et al., 2014; Roberts et al., 2001; Weinstein, 1989; Zohar, 2010). Some research focuses mainly on technical and organizational aspects such as improvements in working conditions, safety climate and job design (Liu et al., 2015; Mullen, 2004; Wolf and Sampson, 2007). With a view towards social psychology however research have also explored how human motivational factors and social norms tied to factory workers themselves rather than their work environment may hold great explanatory power when it comes to workplace accidents and injuries (e.g. Fugas et al., 2012; Griffin and Hu, 2013; Hedelund et al., 2016; Mullen, 2004). Moreover some research combines both person and situational considerations to explain workplace safety in manufacturing environments (Christian et al., 2009). This is important since both are vital to the success of production improvement programs (Boudreau et al., 2003). Although research on workplace safety and safety management in production in this way have evolved, more research focusing on how person and situation factors interact to influence safety is needed (Christian et al., 2009). A detailed and structured approach to understand how workers as individuals are differently motivated to adhere to safe behavior within different safety climates and based on both value-related, identify-related and utilityrelated motivational antecedents is still missing from research. This is the focus and overall objective of the presented research.

The present study contributes by demonstrating the usefulness of the social influence interpretation of worker motivation provided by Sussmann and Vecchio (1982) to the study of safe work behavior. We show how the theory proposed by Sussmann and Vecchio (1982) 
complements the theory of planned behavior as operationalized by Fugas et al. (2012) and others. We show how the different types of motivational antecedents suggested by Sussmann and Vecchio (1982) provide additional structure and insights into the cognitive and social mechanisms that mediate the relationship between organizational safety climate and safety behaviors.

Another major contribution of the present research is that a couple of new antecedents to safe work behavior is hypothesized and tested. First, results from the presented research provide new insights into the relation between factory workers experience with safety and health problems and the behavioral intentions to work safely. The relation was suggested based on the proposition that experience with safety and health problems might have the potential to affect a factory workers core value system. This however seems not to be the case. Results indicate that experience with safety and health problems do not motivate factory workers to adopt less cavalier attitudes towards safety. However, results indicates that experience with safety and health problems may produce less confidence in own abilities to work safely. Results from this study thus indicate that the total effects of a factory workers experience with safety and health problems seems to affect safe work behavior negatively, and that this is caused by a decrease in confidence and abilities to work safely. Second, results from the presented research provide insight into the relation between factory workers knowledge of the factory and the behavioral intentions of workers to work safely. Workers knowledge of the factory is found to hold an especially strong relation to the behavioral intentions of workers to work safely. This may be understood as a process of identification, where factory workers through their involvement and increased knowledge of the products, organization, goals/objectives and customers of the factory becomes socially committed to work safely via their increased attractiveness of membership in the organization (Sussmann and Vecchio, 1982). As the types of knowledge normally explored as related to safe work behavior are closely related to safety procedures and practices, this is a new finding that complements existing research in the area.

This study adds to manufacturing managers' decision making and more generally to safety management practices by suggesting that managers should include considerations as to how their employees can be influenced to avoid engaging in intentional unsafe work behavior by providing them with value-related, identity related and/or utility related incentives. Findings suggest that including such considerations will prove helpful when designing safety performance improvement strategies. Specifically this study shows how manufacturing 
managers should consider involving manufacturing workers when it comes to providing them with more knowledge of the products, organization, goals/objectives and customers.

The remainder of this paper is structured in the following way. First, in the next section the theoretical background is provided. Then the research model and hypothesis is developed. This is followed by a description of the research method and a presentation and discussion of the results. Finally, conclusions are presented as well as limitations and directions for research.

\section{Complementary explanation of unsafe behavior}

Workplace safety is concerned with the study of the antecedents of safety performance in the work place (De Koster et al., 2011; Pagell and Gobeli, 2009; Vinodkumar and Basi, 2011). Safety performance in turn is the extent to which companies are able to prevent accidents and errors from happening (De Koster et al., 2011), and may be affected by a multitude of factors. E.g.: management commitment to safety or safety climate (Brown et al., 2000; Zohar, 2010); degree of workplace pressure (Prussia et al., 2003); the implementation of hazard reducing systems (De Koster et al., 2011); clarity in relation to managerial accountability for safety (Pagell et al., 2014) and the degree of openness about errors (McFadden et al., 2009). These are therefore all potential safety management mechanisms that are practices, roles and functions associated with remaining safe. There have been numerous attempts to identify specific safety management practices that predict safety performance (Vinodkumar and Basi, 2011). Thus literature has explored complementary explanations as to the origins of safety performance and unsafe behavior.

One set of explanations originates from the system itself and how it is designed. The assumption is that system design directly affects safety performance and that management therefore needs to focus carefully on process and manufacturing system design in order to maximize safety performance (Roberts, 1990). Normal accident theory provides a coherent model of system failure and offers insights into the reliability and safety of high consequence technical systems (Wolf and Sampson, 2007). Normal accident theory predicts that those systems having the characteristics of complexity and tight coupling are most at risk of system accidents (Perrow, 2011; Wolf, 2001).

Another set of explanation are the organizational practices put in place in order to enhance reliability and avoid accidents. High reliability theory predicts that organizations that seeks to know what they don't know and consistently communicates what the organization seeks to do 
and try to get everybody to communicate with each other about how they fit in the big picture will achieve a higher safety performance (Roberts et al., 2001). Within high-reliability organizations, employees have learned how to manage errors and risk in a way that has made them remarkably accident-free. Organizational practices are made that promote a higher attention to detail due to a focus on potential failure (Weick and Sutcliffe, 2001). Such a mindset allows individuals to collectively recognize and respond to error signals in their environments during the earliest stages of crisis development (Crowe et al., 2017). Previous research has explored different types of organizational practices promoting increased levels of safety performance (e.g. Allen et al., 2010; Nesheim and Gressgård, 2014; Skjerve et al., 2011; Størseth and Tinmannsvik, 2011). Some research explores after-action reviews and learning as important organizational safety management practices (Allen et al., 2010: Størseth and Tinmannsvik, 2011). Others highlight knowledge sharing mechanism as central to safety management. Nesheim and Gressgård (2014) for instance identified work experience, training, intrinsic motivation, job autonomy, location, and management support as influencing the level of knowledge sharing behavior, which again affects knowledge exploitation related to safe work conduct.

Safety climate and safety culture is generally accepted as another very dominant set of explanation that contribute to explain safe and unsafe behavior (e.g. Cooper and Phillips, 2004; DeJoy et al., 2010; Guldenmund, 2000; Kwon and Kim, 2013; Liu et al., 2015; Mearns et al., 2003; Mearns et al., 2013; Tharaldsen et al., 2008; Zohar, 2010). There are many definitions of safety climate, but in most it is broadly understood as the sum of employees' shared perceptions of the policies, procedures, and practices relating to safety in their work environment (Zohar, 2010). An important question forming employees' safety climate perceptions is whether safety is an organizational priority in relation to other organizational goals, such as productivity or efficiency? (Mearns et al., 2013). Safety climate is therefore related to how employees perceive organizational priorities (Liu et al., 2015; Vinodkumar and Bhasi, 2011).

Yet another set of explanations to the origins of safety performance is employees' safety motivation (Larsson et al., 2008). Here safety management is concerned with providing deliberate designed employee incentives to enhance their safe work behavior. This recognizes that management has a major role in motivating employees to work safely (Griffin and $\mathrm{Hu}$, 2013), and a set of different motivational mechanisms have been explored (e.g. Dejoy et al., 2010; Griffin and Hu, 2013; Hedelund et al., 2010; Hedelund et al., 2016; Kvorning et al., 
2015; Neal et al., 2000; Neal and Griffin, 2006). Griffin and Hu (2013) explored the role of monitoring, inspiring, and learning as three key mechanisms to motivate safety compliance and safety participation. In another recent contribution Hedelund et al., (2016) found that the degree of participation, the number of safety intervention occasions, the primary target group for the safety intervention, and the decision maker of the safety intervention affect safety motivation. However research focusing on employee motivation to work safely is still rather sparse (Hedelund et al., 2016). Although some theoretical underpinnings, such as a distinction between intrinsic motivation and extrinsic motivation (Hedelund et al., 2010) as well as a focus on social exchange and organizational commitment theory (Dejoy et al., 2010) have been provided, more theoretical guidance and structure is needed in order to fully understand employees' motivation to work safely (Eid et al., 2012).

Specifically, theory from within the field of social psychology has the potential to provide such theoretical guidance. A small but emerging part of the literature applies the theory of planned behavior to help clarify the relation between safety climate, motivation and intention to work safely. This literature establishes a deeper understanding of the human factors that contribute to violations of safety (e.g. Fogarty and Shaw, 2010; Fugas et al., 2012). One example is Fogarty and Shaw (2010), who sets out to explore safety violation behavior in aircraft maintenance. Management attitudes, worker attitudes, group norms and work pressure, as well as intention to violate safety procedures are all found to affect safe workplace behavior. Another example is Fugas et al. (2012), who like Fogarty and Shaw (2010) combines safety climate literature and the theory of planned behavior. Specifically the cognitive and social mechanisms that mediate the relationship between organizational safety climate and safety behaviors are explored using data from a transportation organization. Of relevance to this study, the relationship between organizational safety climate and workers compliance based safety behaviors is found to be fully mediated by the supervisors' injunctive safety norms and workers own perceived behavioral control (e.g. safety efficacy).

The recent work by Fogarty and Shaw (2010) and Fugas et al. (2012) have demonstrated the relevance of the theory of planned behavior as useful for understanding the psychological background to the procedural violations of safety. However there are more theories from within the realm of social psychology and social influence theory that holds the potential to help provide a deeper understanding of the human factors that contribute to violations of safety. Specifically the social influence interpretation of worker motivation provided by Sussmann and Vecchio (1982) has a potential to complement the theory of planned behavior 
as it provides additional structure to the set of motivational antecedents that predicts employees' behavioral intentions. A central ambition of this paper is to exemplify the usefulness of the theory provided by Sussmann and Vecchio (1982). How it complements the theory of planned behavior to provide additional insights into the cognitive and social mechanisms that mediate the relationship between organizational safety climate and safety behaviors.

\section{Hypothesis development}

\subsection{A social influence interpretation to worker motivation}

Social influence theory is concerned with understanding the behavioral factors leading to overt behavior. Overt behavior may be concerned with direct observable production behavior and in this case the overt behavior of interest is employees' safe behavior. Social influence theory proposes a two-step approach for the construction of overt/safe behavior.

Firstly, behavioral intentions are linked to the intentions of the employees to engage in overt behavior. In this case the behavioral intention of interest is cavalier attitudes towards safety and safety efficacy which in turn are hypothesized to be related to employees' safe behavior (Brown et al., 2000). Secondly, employees' motivation and behavioral intensions may be understood to be a function of motivational antecedents. Sussmann and Vecchio (1982) point towards three distinct types of motivational antecedents: Value-related; identity-related and/or utility-related. The value-related function is linked to a process of internalization, where factory workers are influenced to engage in safe work behavior because it is congruent with their own value system and/or because it is intrinsically rewarding (Hedelund et al., 2010; Nesheim and Gressgård, 2014). This is a case of pure moral commitment. The identity-related function is linked to a process of identification, where factory workers are influence to work safely in order to engage in a satisfying role relationship with another person or a group. Specifically this may be understood as behavior controlled by the attractiveness of membership in an organization. This is a case of social commitment (Dejoy et al., 2010). Finally, the utility related function is linked to a process of compliance, where factory workers are influenced to engage in safe work behavior in order to gain specific rewards and to avoid punishments. This is a case of calculative or alienative involvement (Sussmann and Vecchio, 1982). 


\subsection{Behavioral intentions}

From social influence theory behavioral intentions are concerned with the motivation of employees to engage in safe work behaviors.

From motivation theory, self-efficacy refers to a person's intentions to mobilize the cognitive resources, motivation, and courses of action needed to meet task demands. Studies of selfefficacy have shown that people who have a high sense of self-efficacy for a particular task perform better than those who have low self-efficacy for that task (Gist and Mitchell, 1992). Self-efficacy is thus strongly related to performance and low self-efficacy expectations regarding a behavior or behavioral domain reversely lead to the avoidance of those behaviors and thus lower levels of overt behavior performance (Wood and Bandura, 1989). Safetyefficacy as a special case of self-efficacy has only received little empirical attention but has been mentioned as a possible determinant of health behaviors in the workplace (DeJoy, 1996; Eid et al., 2012). The relation between safety-efficacy or perceived behavioral control and safe workplace behavior has been tested in previous studies by Brown et al. (2000) and Fugas et al. (2012). This study adopts the definition provided by Brown et al. (2000) and defines safety-efficacy as an employee's confidence that he or she has the skill to work safely in the context of a specific workplace environment.

H1. Safety-efficacy is positively related to safe workplace behavior.

Another relevant behavioral intention of employees to engage in or revert from safe work behaviors is concerned with the willingness of the employee to take intentional or unintentional safety related risks. From social psychology and financial theory individuals differ in their willingness to take risks and this has consequences for the outcome of their decision making and their overt behavior (March and Shapira, 1992). In the case of safety related risk in the workplace the non-safety-risk adverse employee may rationalize risk taking and ignore all or some of the safety procedures (Rundmo, 2000). For the purpose of this study cavalier attitude captures this behavioral intention to engage in workplace behavior that ignores safety procedures. Specifically, a cavalier attitude is defined as the extent to which an employee feels that he or she can ignore safety procedures without incurring the risk of an accident or injury (Brown et al., 2000). However and aligned with previous research which have explored the relation between cavalier attitude, skepticism about the efficacy of safety measures or fatalism and the actual observed safe work behavior (e.g. Brown et al.; Rundmo, 2000; Seo, 2005), a higher level of cavalier attitude or fatalism towards safety is hypothesized to be negatively related to overt safe behavior. 
H2. Cavalier attitudes toward safety, is negatively related to safe workplace behavior.

\subsection{Motivational antecedents}

From social influence theory the motivational antecedents of employees are predictors of behavioral intentions in a work environment (Sussmann and Vecchio, 1982). This study is interested in variables that help predict employees' safety-efficacy and employees' cavalier attitudes towards safety.

Pressure in operations is concerned with "an employee's perception that the organization encourages him or her to work around safety procedures in order to meet production quotas, keep up with the flow of incoming work, meet important deadlines, or continue getting paychecks." (Brown et al., 2000, p.448). It is predicted that when employees perceive organizational pressure as high they will value expediency over safety and this will increase the likelihood that they will assume a more cavalier attitude. It is further hypothesized that a production environment where expediency is perceived as valued over safety will lead employees to feel less able to work safely (McLain and Jarrell, 2007). In such an environment there is not enough time to remove hazards and following safety procedures may interfere with the abilities of the employee to work faster. It is therefore expected that higher levels of pressure to value expediency might undermine an employee's safety-efficacy. The motivational antecedent "pressure" can be understood as an instance of the process of compliance where workers accepts an influence attempt because of a desire to obtain a favorable outcome or to avoid an unfavorable outcome (Sussmann and Vecchio, 1982). A favorable outcome would emerge as a process of a utilitarian organizational power, where employees expect a reward in the form of increased hourly salary because they skip safety procedures and work faster (Boudreau et al., 2003). Avoiding an unfavorable outcome would emerge as a process of a coercive organizational power, where employees engage in alienative involvement in the firm of fear of punishment for not working faster or for not following safety procedures. The relation between pressure and safe work behavior and the behavioral intentions to work safely has been tested in previous studies by McLain and Jarrell (2007) and Brown et al. (2000).

H3A. Pressure is positively related to employees' cavalier attitudes toward safety.

H3B. Pressure is negatively related to employees' safety-efficacy.

Organizational commitment has been explored widely in organizational theory (Kanter, 1968; Mowday et al., 2013; Sheldon, 1971). Organizational commitment is an attitude or an 
orientation towards the organization which links or attaches the identity of the employee to the organization (Sheldon, 1971). Organizational commitment can further be expressed as the willingness of employees to give their energy and loyalty to the organization (Kanter, 1968). Previous research has shown that attachment to an organization or organizational commitment motivates the employee to refrain from behaviors that may harm the relationship to the organization and its members (Thau et al., 2007). Previous research has also demonstrated how employee involvement and human resource practices may be decisive factors that affect the level of health and safety performance (Dejoy et al., 2010; Hedelund et al., 2016; Longoni et al., 2013).

Increasing employees' knowledge of the factory is a socialization mechanism that can be understood to help integrate the goals of the organization with those of the individual employee (Chatzoudes et al., 2015), herby increasing organizational commitment (Hall et al., 1970). When employees know more about the organization, its customers, its products and strategic objectives, this will help support employees believe that the norms and values of the organization represent an important guide to suitable behaviors. Based on these observations and from social influence theory it is expected that employees' knowledge of the factory is a motivational antecedent that may influence the behavioral intentions of the employees to work safely. This study hypothesizes that increased knowledge of the factory acts as a social identification mechanism that increases the social and organizational commitment of the worker to adopt more safety oriented behavioral intentions (Kanter, 1968; Mowday et al., 2013). Simply knowing more about the firm, its customer, products and objectives is expected to increase the social attachment to the organization, promote an identity of belonging, and therefore the intentions to follow organizational safety procedures and regulations. It is therefore expected that higher levels of knowledge of the factory will reduce employees' cavalier attitudes toward safety. Another expected effect leading from increased knowledge of the factory and the process of identification is proposed to be linked to job scope and a sense of importance of the role of the employee to the operation (Kanter, 1968), more job security, and an increased feeling of confidence and ability to work safely. Employees are thought to respond positively when provided with more knowledge and challenges in their job (Mowday et al., 2013). It is therefore expected that higher levels of knowledge of the factory may have a positive effect on employee's safety-efficacy.

H4A. Employees' knowledge of the factory is negatively related to employees' cavalier attitudes toward safety. 
H4B. Employees' knowledge of the factory is positively related to employees' safetyefficacy.

Experience with safety and health problem is defined as an employee's experience with work related accidents and health problems stemming from previous work. Experience can emanate from personal experienced injury or health problem or it can be based on previous observations of colleagues' health problems or accidents. From literature it is speculated; that this variable may relate strongly to the behavioral intentions to work safely (Pagell and Gobeli 2009; Zhou et al., 2008). Pagell and Gobeli (2009) explored how experience with employee well-being issues may form managers' attitudes to employee safety and well-being. Zhou et al. (2008) found that personal experience factors related to safety was strong predictors of safe behavior. From Sussmann and Vecchio (1982) it is hypothesized that high levels of experience with severe safety and health problems may affect an employee's value system. Experience with safety and health problems may be related to a process of internalization and pure moral commitment to intend to follow safety procedures and engage in safer behavior. It is thus predicted that when employees have experience with safety and health problems this will decrease the likelihood that they will assume a more cavalier attitude. However experience with safety and health problems might also lead to the perceived inability to remove future hazards and escape health problems. It is thus predicted that when employees have experience with safety and health problems this will have a negative effect on safetyefficacy. Finally if employees have experienced safety and health related problems, especially from within the organization, it communicates to employees that the organization has other priorities.

H5A. Employees experience with safety and health problem is negatively related to employees' cavalier attitudes toward safety.

H5B. Employees experience with safety and health problem is negatively related to employees' safety-efficacy.

H5C. Employees experience with safety and health problem is positively related to pressure.

\subsection{Safety hazards and safety climate}

Safety hazards are defined as tangible factors in the work environment that may pose risks for possible injuries or ailments. The assumption is that when employees perceives high levels of safety hazards this sends a signal that the company carries a low commitment to health and safety, and therefore impact safety climate in a negative way (Zohar, 2010). Another effect of higher levels of perceived safety hazards that are suggested and tested in previous literature 
by Brown et al. (2000) is its impact on perceived pressure. "If employees believe that managers do not care enough to remove hazards, it communicates to employees that the organization has other priorities" (Brown et al., 2000, p.450). Safety climate is defined as employees' moral perceptions of the role of safety within the organization. It is predicted that if employees perceives the system safety moral as low, they will consider this as an additional factor that there is pressure to take safety shortcuts.

H6A. Safety hazards is negatively related to safety climate.

H6B. Safety hazards is positively related to pressure.

H6C. Safety climate is negatively related to pressure.

$<<$ Insert Figure 1 about here $>>$

\section{Research method}

\subsection{Variable measurement}

Safe workplace behavior was assessed using a two item variable (Brown et al., 2000). First the employee was asked to assess what percentage of the time they themselves followed safety procedures. The second variable asked what percentage of time their coworkers followed safe work practices. Cronbach's $\alpha$ for this variable was estimated to 0.92. Both cavalier attitudes towards safety, safety efficacy and pressure was measured using a 7 point Likert-type scale ranging from 1 (never/strongly disagree) to 7 (very often/strongly disagree) and using scales developed by Brown et al. (2000) (see Appendix A). Cronbach's $\alpha$ for these variables was estimated to $0.82,0.89$ and 0.80 respectively.

Safety climate was measured using a nine item construct and a 7 point Likert-type scale ranging from 1 (strongly disagree) to 7 (strongly agree) (Brown et al., 2000). Cronbach's $\alpha$ for this variable was estimated to 0.90 .

The variable "safety hazards" was measured taking the 42 hazard items from Brown et al. (2000) into consideration. However and primarily due to the new industrial setting, the list of hazard items was simplified, and this resulted in a 28 item construct (see Appendix A). To create the adjusted set, three of the factories representing the sample were visited and an interview with an expert knowing in detail all the participating sample factories was performed. A safety hazard importance score was calculated for each hazard by summing its seriousness rating with its frequency rating. 
In order to capture employee experience with safety and health problems a new four item measure was constructed. The construct was measured using a seven point Likert scale with anchors of 1 never/strongly disagree and 7 very often/strongly agree. First respondents were asked to rate the frequency with which collegial work related accidents and health problems had been witnessed. Second respondents were asked to rate the frequency with which such safety and health problems had been experienced personally. As was the case with the measure "safe workplace behavior", both questions were included to increase the validity related to self-reported behavior. Experience with co-worker accidents averaged 2.57 $($ S.D. $=1.46)$. Estimates of own work related accidents averaged as expected lower at 1.51 (S.D.=1.19). Experience with co-worker work related health problems averaged 2.11 $($ S.D. $=1.56)$. Estimates of own work related illness averaged as expected again lower at 1.46 (S.D.=1.14). Cronbach's $\alpha$ for this variable was estimated to 0.70 .

Employees' knowledge of the factory is measured aiming to capture four different dimensions of employees' knowledge related to the firm and the factory where they work. In order to capture these dimensions a 7 point Likert-type scale ranging from 1 (strongly disagree) to 7 (strongly agree), and a new four item measure was therefore constructed. The four different dimensions of employees knowledge of the factory was constructed based on a study of the literature and based on initial interviews with firm representatives. Questions were organized in what was expected to be a sort of hierarchy of knowledge, where the dimensions that was most visible to employees, and was expected to score the highest, was asked first. First, knowledge of the products produced in the factory averaged 5.64 (S.D.=1.72). Second knowledge of the formal organization of the factory averaged 5.25 (S.D.=1.74). Third knowledge of the goals and objectives of the factory averaged 4.96 (S.D.=1.98). Finally knowledge of the customers of the factory averaged 4.47 (S.D.=2.09). Cronbach's $\alpha$ for this variable was estimated to 0.85 . Appendix Table A1 details the survey items.

\subsection{Sampling and data collection}

A survey was handed out to 570 factory workers in seven different factories owned by seven different firms in China. The firms all had Chinese or Hong Kong Chinese ownership. The factories all delivered products to the same buying firm, were suppliers within the electronics industry and represented a homogeneous group of factory working environments. Although the sizes of the seven supplying firms varied, the buying firm in all cases only represented a very small portion of their total turnover. Thus potential issues of response bias caused by dependence were minimized. In each factory a random sample of employees were selected. 
Sample sizes across factories in the final sample varied from 54 to 92 respondents, with a standard deviation of 14.1.

The surveys were distributed inside regular working hours and not during a break. The selected factory workers were instructed as to the purpose and procedure of filling it out. Workers were ensured individual anonymity in all aspect. In order to avoid response bias caused by fear for work related punishment, management was not present or engaged in the process when their workers filled out the questionnaire. To understand whether there were challenges with social desirability or the ability to speak freely, two factory workers and one supervisor was selected randomly and interviewed in each plant. The purpose of these interviews was to understand how the selected factory workers rationalized their assessment of the constructs, and especially the assessment of the variable safety climate. Also secondary data in the form of social compliance audit reports and interviews with plan top management was used as a source to assess whether there were issues of concern related to the level of social desirability. All seven factories performed well in the social compliance audit reports, which may be a strong indicator for a good work environment and an environment where workers are allowed to speak freely. This resulted in a sample of 428 completed questionnaires, producing a usable response rate of $75 \%$. Table 1 provides the sample descriptions in terms of gender and age of the final sample. Missed values were treated by excluding cases pairwise, which still made partly filled out questionnaires valuable to the analysis. Response rates on the specific questions in the final sample ranged from $79 \%$ to $100 \%$, which were perceived as highly satisfactory. Non-response bias was assessed by examining the difference between respondents and non-respondents on the variables of interest (Forza, 2002). No significant differences were found in any of the comparisons indicating the absence of non-response bias.

$<<$ Insert Table 1 about here $>>$

\subsection{Reliability and validity}

In order to test the formulated hypotheses in the structural model (Figure 1), Partial Least Squares Structural Equation Modeling (PLS-SEM), SmartPLS package version 3.1.9, (Ringle et al., 2005) with PLS method was used (Finney and DiStefano, 2006). PLS-SEM, is based on variance maximization, and was chosen as it is more suitable than covariance-based techniques, such as LISREL, in handling categorical data (Hair et al., 2014, Saghiri and Hill, 2014). PLS-SEM is also more useful for exploratory studies where theory is still being 
developed (Youn et al., 2012), and is relevant for this study since new measures such as "Employees' knowledge of the factory" and "Experience with safety and health problems" are developed. Finally this study benefits from the advantage of PLS-SEM in terms of less rigorous requirement of restrictive assumptions (Youn et al., 2012).

Prior to data collection, content validity was supported by previous literature and pilot interviews with industry experts. A total of five interviews were conducted, transcribed and subsequently coded using principles from Miles and Huberman (1994). Together with literature, analysis of interviews identified "Employees' knowledge of the factory" and "Experience with safety and health problems" as two potential highly relevant antecedents to safe employee behavior in the context explored.

After data collection, a series of analysis was performed to test the reliability and validity of the constructs. All constructs in this research are modelled as reflective. The reflective approach suggests that the underlying constructs causes their indicators (Roberts et al., 2010), and this fits well with the measures used in this study. As a result classical test theory, reliability estimation and factor analysis can be applied.

To test whether it was appropriate to combine data from the seven factories, a model where all factor loadings were constrained to be equal was compared to a model where factor loadings were free to vary across groups. An insignificant chi-square difference indicated that the measures were interpreted similarly across factories.

To test construct reliability the two-step method described in Narasimhan and Jayaram (1998) was used, employing Cronbach's alpha for assessing construct reliability and exploratory factor analysis (EFA) to ensure unidimensionality. First, and as indicated in table 2, Cronbach's alpha and composite reliability are all above or extremely near the recommended 0.70 cut-off threshold (Cronbach, 1951; Nunnally, 1978). Second, EFA with principal component analysis was used for data reduction and for determining the main constructs measured by the items from previous studies or newly developed items. Measurement items all had strong loadings on the construct they were supposed to measure, and lower loadings on the constructs they were not supposed to measure.

To test construct validity of the various elements of the research model, standard CFA metrics of factor loading was used (Anderson and Gerbing, 1988). All observable variables load significantly at the 0.01 level on their respective latent constructs and all standardized factor loading coefficients are greater than 0.50 . Convergent validity is also demonstrated by the 
high levels of AVE, ranging from 0.519 to 0.925 , well above the suggested level of 0.50 (Fornell and Larcker, 1981). Moreover discriminant validity was assessed using the FornellLarcker Criterion (Fornell and Larcker, 1981). The result of the Fornell-Larcker test is presented in Table 2. It shows that all values have the strongest relationships with its own indicators (Hair et al., 2014). The level of explained variance on the constructs is high to medium: Safe workplace behavior $\left(R^{2}=0.415\right)$; Cavalier attitudes $\left(R^{2}=0.337\right)$; Safety efficacy $\left(R^{2}=0.271\right)$; Pressure $\left(R^{2}=0.266\right)$; Safety climate $\left(R^{2}=0.153\right)$.

$<<$ Insert Table 2 about here $>>$

\section{Results}

In total 12 hypotheses was formulated and tested. In order to test the formulated hypotheses PLS-SEM was used. The strength, direction and level of significance of the path coefficients were estimated using a bootstrap resampling method. Following recommendation from literature and to make sure parameter estimates were stable the final model used 5000 resamples (Shrout and Bolger, 2002). Figure 2 presents the estimated structural equation model. Table 3 presents the detailed results of the hypotheses tests.

$$
\begin{aligned}
& <<\text { Insert Figure } 2 \text { about here }>> \\
& <<\text { Insert Table } 3 \text { about here }>>
\end{aligned}
$$

In summary and as indicated in table 3, ten out of the twelve hypotheses were supported and only $\mathrm{H} 5 \mathrm{~A}$ and $\mathrm{H} 5 \mathrm{C}$ were not supported.

Specifically and related to behavioral intentions and its relation to safe work behavior significant and strong relationships were found. First, the path coefficient from safety efficacy to safe workplace behavior is statistically significant, supporting $\mathrm{H} 1(0.296, \mathrm{t}=5.005, \mathrm{p}<0.01)$. Second, the path coefficient from cavalier attitudes towards safety to safe workplace behavior is statistically significant, supporting $\mathrm{H} 2(-0.226, \mathrm{t}=3.204, \mathrm{p}<0.01)$.

Regarding motivational antecedents and its relation to behavioral intentions three types of motivational antecedents are explored. Some of these relations, especially the utility related and the identity related showed significant and strong to moderate relationships. However the value related motivational antecedent was found to demonstrate non-significant or significant weak relationships with behavioral intentions. First, pressure represents a utility related variable. The path coefficient from pressure to cavalier attitudes towards safety is statistically significant, supporting $\mathrm{H} 3 \mathrm{~A}(0.441, \mathrm{t}=7.697, \mathrm{p}<0.01)$. The path coefficient from pressure to 
safety efficacy is also statistically significant, supporting H3B $(-0.134, \mathrm{t}=2.007, \mathrm{p}<0.05)$. Second, employees' knowledge of the factory represents an identity related variable. The path coefficient from employees' knowledge of the factory to cavalier attitudes towards safety is statistically significant, supporting H4A $(-0.141, \mathrm{t}=2.383, \mathrm{p}<0.05)$. The path coefficient from employees' knowledge of the factory to safety efficacy is also statistically significant, supporting H4B $(0.360, t=5.624, p<0.01)$. Third, experience with safety and health problems represent a value related variable. The path coefficient from experience with safety and health problems to cavalier attitudes towards safety is statistically non-significant, and $\mathrm{H} 5 \mathrm{~A}$ is therefore not supported $(0.085, \mathrm{t}=1.176, \mathrm{p}>0.10)$. The path coefficient from experience with safety and health problems to safety efficacy is statistically significant, supporting H5B ($0.122, \mathrm{t}=1.898, \mathrm{p}<0.10$ ). Finally the relation between experience with safety and health problems and pressure is also explored and is found to be non-significant, $\mathrm{H} 5 \mathrm{C}$ is therefore not supported $(0.022, \mathrm{t}=0.344, \mathrm{p}>0.10)$.

Related to safety hazards and safety climate three hypothesis are tested and all found to be significant. First, the path coefficient from safety hazards to safety climate is statistically significant, supporting H6A $(-0.157, \mathrm{t}=2.005, \mathrm{p}<0.05)$. Second, the path coefficient from safety hazards to pressure is statistically significant, supporting H6B $(0.328,6.032, p<0.01)$. Finally, the path coefficient from safety climate to pressure is statistically significant, supporting H6C $(-0.155, \mathrm{t}=2.394, \mathrm{p}<0.05)$.

\section{Discussion and conclusion}

This research sought to complement literature discussing the cognitive and social mechanisms that mediate the relationship between organizational safety climate and safety behaviors. This was done based on the social influence interpretation of worker motivation provided by Sussmann and Vecchio (1982). Results point towards three main sets of conclusions and contributions.

Results show the usefulness of the social influence interpretation of worker motivation provided by Sussmann and Vecchio (1982) in explaining safety behaviors. The present study corroborates Fogarty and Shaw (2010) and finds support for the relation between safety climate and work pressure as well as between work pressure and cavalier attitudes. The present study further corroborates and complements Fogarty and Shaw (2010) and Fugas et al. (2012) by adding the identity related variable "employees' knowledge of the factory" as an alternative to group or coworker norms and further by highlighting the potential to 
incorporate explanations related to workers own value systems in the model. This shows how the social influence interpretation of worker motivation provided by Sussmann and Vecchio (1982) may be operationalized to complement the theory of planned behavior. The model explored here builds in part on a model developed and tested by Brown et al. (2000) using data from the US steel industry. All hypotheses from the original model are here reconfirmed in the specific part of the Chinese manufacturing sector setting explored in this study. Following the meta-analysis on workplace safety provided by Christian et al. (2009) the present study further adds additional structure and new insights into the chain of causality leading from safety climate to safety motivation and safety performance. Specifically the operationalization of the value-related, identity related and/or utility related motivational antecedents suggested here is new.

Second, factory workers knowledge of the factory has strong relations to the behavioral intentions of workers to work safely. Here findings indicate that factory workers with more knowledge of the products, organization, goals/objectives and customers of the factory demonstrated a higher level of safe work behavior on almost all dimensions, as compared to their ignorant colleagues. Thus the level of knowledge of the factory is a strong predictor of safe work behavior. This may be understood as a process of identification, where factory workers through their involvement and increased knowledge of the factory are socially committed and influenced to work safely via their increased attractiveness of membership in the organization (Sussmann and Vecchio, 1982). Findings thus indicate that knowledge of the factory may be a particular strong mechanism to influence workers to work more safely and that this may be understood to function via a process of motivation and influence through identification. In particular strong evidence are found that increased knowledge of the factory directly affects a factory workers confidence in own abilities to work safely (i.e. safety efficacy). This finding complements previous research that has found positive effects of knowledge sharing on employees' actions in terms of safety (Nesheim and Gressgård, 2014). This finding also complements safety management research that highlights social exchange and organizational commitment as important to safety motivation (Dejoy et al., 2010). Here employees' knowledge of the factory works as an organizational commitment mechanism and this shows how knowledge can be important not only as information sharing in and around safety procedures (e.g. Safety Knowledge) (Christian et al., 2009), but also as a social influence mechanism that attaches the factory worker socially to the organization. Finally, this finding is also consistent with a view that sees knowledge, involvement and training as 
powerful influencing mechanism within production and operations management settings (Longoni et al., 2014; Mellat-Parast, 2013).

Third, the hypothesized relation between factory workers experience with safety and health problems and the behavioral intentions to work safely was developed based on the proposition that experience with safety and health problems might have the potential to affect a factory workers core value system (Weinstein, 1989). This however seems not to be the case. Results indicate that experience with safety and health problems do not motivate factory workers to adopt less cavalier attitudes towards safety (i.e. H5A). This finding complements Zhou et al. (2008) who found that other dimensions of personal experience factors related to safety was strong predictors of safe behavior. I addition it corroborates Leiter et al. (2009) that found that no significant relation could be found between experience of injury and stricter adherence to safety regulations. However, results also extends Leiter et al. (2009), indicating that experience with safety and health problems may produce less confidence in own abilities to work safely (i.e. H5B). In summary, results from this study indicate that the total effects of a factory workers experience with safety and health problems seems to affect safe work behavior negatively, and that this is caused by a decrease in confidence and abilities to work safely.

For practitioners results are important because the structural model predict how employees may be influenced to work more safely. Manufacturing managers can increase the level of safety performance by managing a diverse set of motivational antecedents. Specifically, findings indicate that knowledge of the factory may be a very powerful internalization mechanism, having the ability to influence factory workers to adopt positive behavioral intentions towards safety. Thus manufacturing managers should consider informing and educating their employees on the products, organization, goals/objectives and customers of the factory. Especially the relation to increased safety efficacy is strong. Findings also indicate that manufacturing managers may find it useful to consider and hire factory worker profiles which hold identities and core value systems aligned with safe behavior. Specifically this research found that previous experience with safety and health problems may lead to less confidence in own abilities to remove safety hazards and overall may have a negatively effect on safety performance. Finally, manufacturing managers should also understand how the adoption of reward-based or punitive-oriented compliance such as pressure may work to enable or constrain factory workers to engage in safe work behavior. 
However like any other study this study has limitations. First, one limitation of this research has to do with the sample composition. Future research could examine other factories, industries, cultures and countries to ensure that results are not specific to a specific context. Also future research could examine potential differences between age-groups or men's and women's safety perceptions. Second, there are limitations using the survey approach. Adopting a multiple case study approach with more qualitative interviews as a supplement to this study could have been useful in order to identify the specific reasoning and decision making involved in forming the identified behaviors. Third, there may be limitations attached to the choice of the sampling procedure. Using seven different although highly homogeneous factories may potentially lead to noise in the data that could have been avoided if only one factory had been used. Fourth, although claiming the relevance of the social influence interpretation of worker motivation provided by Sussmann and Vecchio (1982), the purpose here was not to test the theory and all of its assumptions. Therefore the model tested in this paper only operationalizes some of the assumptions and variables to exemplify its relevance. Finally, there are some model test limitations as well. The focus of the presented research was to test the developed hypothesis, and therefore some of the mediation assumptions and direct and indirect effects were not considered in the paper.

In relation to future research, more studies should explore how the social influence interpretation of worker motivation provided by Sussmann and Vecchio (1982) can be applied to the study of occupational health and safety within production and operations management. This theory seems to have a potential as a powerful explanation why employees are motivated to work safely. Together with operationalization's of the theory of planned behavior (e.g. Fogarty and Shaw, 2010; Fugas et al., 2012) it may be a fruitful avenue for future research interested in understanding the cognitive and social mechanisms that mediate the relationship between organizational safety climate and safety behaviors. Specifically future research might help retest the motivational antecedents identified in this study and further identify and test additional motivational antecedents. What aspects of knowledge of the factory are in particular important in influencing the behavioral intentions to work safely? Which internalizations mechanisms are available to managers when managing to increase safe work behavior amongst employees? Which reward-based or punitive-oriented interpersonal influencing mechanisms to increase safe work behavior works best in specific production and operations environments? These and other similar questions are all important to research and 
to practice in our continued efforts to increase knowledge and performance on occupational health and safety within production and operations management.

\section{References}

Allen, J. A., Baran, B.E., Scott, C.W. 2010. After-action reviews: A venue for the promotion of safety climate. Accident Analysis \& Prevention, 42(2), 750-757.

Anderson, J.C., Gerbing, D.W. 1988. Structural equation modeling in practice: a review and recommended two-step approach. Psychological Bulletin, 103(3), 411-423.

Boudreau, J., Hopp, W., McClain, J.O., Thomas, J.L. 2003. On the Interface Between Operations and Human Resources Management. Manufacturing \& Service Operations Management, 5(3), 179-202.

Brown, K.A., Willis, P.O., Prussia, G.E. 2000. Predicting safe employee behavior in the steel industry: development and test of a sociotechnical model, Journal of Operations Management, 18(4), 445-465.

Chatzoudes, D., Chatzoglou, P., Vraimaki, E. 2015. The central role of knowledge management in business operations: Developing a new conceptual framework. Business Process Management Journal, 21(5), 1117-1139.

Christian, M.S., Bradley, J.C., Wallace, J.C., Burke, M.J. 2009. Workplace safety: a metaanalysis of the roles of person and situation factors. Journal of Applied Psychology, 94(5), 1103-1127.

Cooper, M.D., Phillips, R.A. 2004. Exploratory analysis of the safety climate and safety behavior relationship. Journal of Safety Research, 35, 497-512.

Cronbach, L.J. 1951. Coefficient alpha and the internal structure of tests. Psychometrika, 16, 297-334.

Crowe, J., Allen, J. A., Scott, C. W., Harms, M., Yoerger, M. 2017. After-action reviews: The good behavior, the bad behavior, and why we should care. Safety science, 96, 84-92.

DeJoy, D.M. 1996. Theoretical models of health behavior and workplace self-protection, Journal of Safety Research, 27(2), 61-72.

DeJoy, D.M., Della, L.J., Vandenberg, R.J., Wilson, M.G. 2010. Making work safer: Testing a model of social exchange and safety management. Journal of safety research, 41(2), 163171.

De Koster, R.B.M., Stam, D., Balk, B.M. 2011. Accidents happen: The influence of safetyspecific transformational leadership, safety consciousness, and hazard reducing systems on warehouse accidents, Journal of Operations Management, 29(7), 753-765.

Eid, J., Mearns, K., Larsson, G., Laberg, J.C., Johnsen, B.H. 2012. Leadership, psychological capital and safety research: Conceptual issues and future research questions. Safety science, 50(1), 55-61.

Fan, D., Lo, C.K.Y., Ching, V., Kan, C.W. 2014. Occupational health and safety issues in operations management: A systematic and citation network analysis review. International Journal of Production Economics, 158, 334-344.

Fernandez-Muniz, B., Montes-Peon, J.M., Vazquez-Ordas, C.J. 2009. Relation between occupational health and safety management and firm performance, Safety Science, 47, 980-991.

Finney, S.J., DiStefano, C. 2006. Non-normal and Categorical Data in Structural Equation Modeling. In Structural Equation Modeling: A Second Course, edited by G. R. Hancock and R. O. Mueller, 269-314. Greenwich, CT: Information Age.

Fogarty, G.J., Shaw, A. 2010. Safety climate and the Theory of Planned Behavior: Towards the prediction of unsafe behavior. Accident Analysis and Prevention, 42(5), 1455-1459. 
Fornell, C., Larcker, D.F. 1981. Evaluating structural equation models with unobservable variables and measurement error. Journal of Marketing Research, 18(1), 39-50.

Forza, C. 2002. Survey research in operations management: a process-based perspective. International Journal of Operations \& Production Management, 22(2), 152-194.

Fugas, C.S., Sliva, S.A., Meliá, J.L. 2012. Another look at safety climarte and safety behaviour: Deepening the cognitive and social mediator mechanisms. Accident Analysis and Prevetion, 45, 468-477.

Gist, M.E., Mitchell, T.R. 1992. Self-efficacy: a theoretical analysis of its determinants and malleability. Academy of Management Review, 17(2), 183-211.

Griffin, M.A., Hu, X., 2013. How leaders differentially motivate safety compliance and safety participation: the role of monitoring, inspiring, and learning. Safety Science. 60, 196-202.

Guldenmund, F.W. (2000). The nature of safety culture: A review of theory and research. Safety Science, 34, 215-257.

Hair, J.F., Hult, G.T.M., Ringle, C.M., Sarstedt, M. 2014. A Primer on Partial Least Squares Structural Equation Modeling (PLS-SEM), Sage: Thousand Oaks.

Hall, D.T., Schneider, B., Nygren, H.T. 1970. Personal factors in organizational identification. Administrative science quarterly, 176-190.

Hedlund, A., Åteg, M., Andersson, I.-M., Rosén, G. 2010. Assessing motivation for work environment improvements: internal consistency, reliability and factorial structure. Journal of Safety Research, 41, 145-151.

Hedlund, A., Gummesson, K., Rydell, A., Andersson, M. 2016. Safety motivation at work: Evaluation of changes from six interventions. Safety science, 82, 155-163.

Kanter, R.M. 1968. Commitment and social organization: A study of commitment mechanisms in utopian communities. American sociological review, 499-517.

Kvorning, L.V., Hasle, P., Christensen, U., 2015. Motivational factors influencing small construction and auto repair enterprises to participate in occupational health and safety programmes. Safety Science. 71, 253-263

Kwon, O.J., Kim, Y.S., 2013. An analysis of safeness of work environment in Korean manufacturing: the "safety climate" perspective. Safety Science. 53, 233-239.

Larsson, S., Pousette, A., Törner, M. 2008. Psychological climate and safety in the construction industry-mediated influence on safety behaviour. Safety Science, 46(3), 405412.

Leiter, M., Zanaletti, W., Argentero, P. 2009. Occupational risk perception, safety training, and injury prevention: Testing a model in the Italian printing industry. Journal of Occupational Health Psychology, 14(1), 1-10.

Liu, X., Huang, G., Huang, H., Wang, S., Xiao, Y., Chen, W. 2015. Safety climate, safety behavior, and worker injuries in the Chinese manufacturing industry. Safety science, 78, 173-178.

Loeppke, R., Taitel, M., Richling, D., Parry, T., Kessler, R.C., Hymel, P., Konicki, D. 2007. Health and productivity as a business strategy. Journal of Occupational and Environmental Medicine, 49, 712-721.

Longoni, A, Pagell, M., Johnston, D., Veltri, A. 2013. When does lean hurt? - an exploration of lean practices and worker health and safety outcomes. International Journal of Production Research, 51(11), 3300-3320.

Longoni, A., Golini, R., Cagliano, R. 2014. The role of New Forms of Work Organization in developing sustainability strategies in operations. International Journal of Production Economics, 147 Part A, 147-160.

March, J., Shapira, Z. 1992. Variable risk preferences and the forces of attention. Psychological Review, 99(1), 172-183. 
McFadden K.L., Henagan, S.C., Gowen, C.R. 2009. The patient safety chain: transformational leadership's effect on patient safety culture, initiatives, and outcomes. Journal of Operations Management, 27, 390-404.

McLain, D. L., Jarrell, K. A. 2007. The perceived compatibility of safety and production expectations in hazardous occupations. Journal of safety Research, 38(3), 299-309.

Mearns, K., Whitaker, S., Flin, R., 2003. Safety climate, safety management practice and safety performance in offshore environments. Safety Science, 41, 641-680.

Mearns, K., Kirwan, B., Reader, T.W., Jackson, J., Kennedy, R., Gordon, R., 2013. Development of a methodology for understanding and enhancing safety culture in Air Traffic Management. Safety Science, 53, 123-133.

Mellat-Parast, M. 2013. Quality citizenship, employee involvement, and operational performance: an empirical investigation. International Journal of Production Research, 51(10), 2805-2820.

Miles, M.B., Huberman, A.M. 1994. Qualitative Data Analysis: Grounded Theory Procedures and Techniques. Sage Publications, London.

Mowday, R.T., Porter, L.W. and Steers, R.M. 2013. Employee-organization linkages: The psychology of commitment, absenteeism, and turnover. Academic press.

Mullen, J. 2004. Investigating factors that influence individual safety behavior at work. Journal of safety research, 35(3), 275-285.

Narasimhan, R., Jayaram, J. 1998. An empirical investigation of the antecedents and consequences of manufacturing goal achievement in North American, European and Pan Pacific firms. Journal of Operations Management, 16(2/3), 159-176.

Neal, A., Griffin, M.A., Hart, P.M., 2000. The impact of organizational climate on safety climate and individual behaviour. Safety Science 34, 99-109.

Neal, A., Griffin, M. 2006. A Study of the Lagged Relationships Among Safety Climate, Safety Motivation, Safety Behavior, and Accidents at the Individual and Group Levels. Journal of Applied Psychology, 91(4), 946-953.

Nesheim, T., Gressgård, L.J. 2014. Knowledge sharing in a complex organization: Antecedents and safety effects. Safety science, 62, 28-36.

Nunnally, J.C. 1978. Psychometric Theory, McGraw Hill, New York, NY.

Pagell, M., Gobeli, D. 2009. How plant managers' experiences and attitudes toward sustainability relate to operational performance. Production and Operations Management, 18(3), 278-299.

Pagell, M. Johnston, D., Veltri, A., Klassen, R., Biehl, M. 2014. Is Safe Production an Oxymoron? Production \& Operations Management, 23(7), 1161-1175.

Perrow, C. 2011. Normal accidents: Living with high risk technologies. Princeton University Press.

Prussia, G.E., Brown, K.A., Willis, P.G. 2003. Mental models of safety: do managers and employees see eye to eye? Journal of Safety Research, 34, 143-156.

Ringle, C.M., Wende, S., Will, A. 2005. SmartPLS 3, available at: http://www.smartpls.com. (Accessed 20 May 2017).

Roberts, K.H. 1990. Some characteristics of one type of high reliability organization. Organization Science, 1, 160-176.

Roberts, K.H., Bea, R., Bartles, D.L. 2001. Must accidents happen? Lessons from highreliability organizations. The Academy of Management Executive, 15(3), 70-78.

Roberts, N., Thatcher, J.B., Grover, V. 2010. Advancing operations management theory using exploratory structural equation modelling techniques. International Journal of Production research, 48(15), 4329-4953.

Rundmo, T. 2000. Safety climate, attitudes and risk perception in Norsk hydro. Safety Science, 34, 47-59. 
Saghiri, S.S., Hill, A. 2014. Supplier relationship impacts on postponement strategies", International Journal of Production Research, 52(7), 2134-2153.

Seo, D.C. 2005. An explicative model of unsafe work behavior. Safety Science, 43(3), $187-$ 211.

Sheldon, M.E. 1971. Investments and involvements as mechanisms producing commitment to the organization. Administrative science quarterly, 143-150.

Shrout, P.E., Bolger, N. 2002. Mediation in experimental and nonexperimental studies: New procedures and recommendations. Psychological methods, 7(4), 422-445.

Skjerve, A.B., Kaarstad, M., Størseth, F., Wærø, I., Grøtan, T.O., 2011. Planning for resilient collaboration at a new petroleum installation - a case study of a coaching approach. Safety Science, 50, 1952-1959.

Størseth, F., Tinmannsvik, R.K., 2011. The critical re-action. Learning from accidents. Safety Science, 50, 1977-1982.

Sussmann, M., Vecchio, R.P. 1982. A Social Influence Interpretation of Worker Motivation. Academy of Management Review, 7(2), 177-186.

Thau, S., Crossley, C., Bennett, R., Sczesny, S. 2007. The relationship between trust, attachment, and antisocial work behaviors. Human Relations, 60(8), 1155-1179.

Tharaldsen, J.E., Olsen, E., Rundmo, T., 2008. A longitudinal study of safety climate on the Norwegian continental shelf. Safety Science, 46, 427-439.

Vinodkumar, M.N., Bhasi, M. 2011. A study on the impact of management system certification on safety management. Safety science, 49(3), 498-507.

Weick, K.E., Sutcliffe, K.M., 2001. Managing the Unexpected: Assuring High Performance in an Age of Complexity. Jossey-Bass, San Francisco.

Weinstein, N.D. 1989. Effects of personal experience on self-protective behavior. Psychological Bulletin, 105(1), 31-50.

Wolf, F.G. 2001. Operationalizing and testing normal accidents theory in petrochemical plants and refineries. Production and Operations Management, 10(3), 292-305.

Wolf, F., Sampson, P. 2007. Evidence of an interaction involving complexity and coupling as predicted by normal accident theory. Journal of Contingencies and Crisis Management, 15(3), 123-133.

Wood, R.E., Bandura A. 1989. Social and cognitive theory of organizational management. Academy of Management Review, 14(3), 361-384.

Youn, S., Yang, M. (Mark), Hong, P. 2012. Integrative leadership for effective supply chain implementation: An empirical study of Korean firms. International Journal of Production Economics, 139(1), 237-246.

Zhou, Q., Fang, D., Wang, X. 2008. A method to identify strategies for the improvement of human safety behavior by considering safety climate and personal experience. Safety Science, 46(10), 1406-1419.

Zohar, D. 2010. Thirty years of safety climate research: Reflections and future directions. Accident Analysis \& Prevention, 42(5), 1517-1522. 


\section{Appendix A}

Table A1. Summary of survey items.

\begin{tabular}{|c|c|c|c|c|}
\hline Construct & Descriptions (scales) of items & Mean & S.D. & Loading \\
\hline $\begin{array}{l}\text { Safe workplace } \\
\text { behavior }\end{array}$ & $\begin{array}{l}\text { Scale from } 0 \% \text { to } 100 \% \\
\text { - What percent of the time do you follow all of the safety procedures for the jobs that you do? } \\
\text { - What percentages of time do your co-workers followed safe work practices? }\end{array}$ & $\begin{array}{l}82.360 \\
83.505\end{array}$ & $\begin{array}{l}19.955 \\
18.535\end{array}$ & $\begin{array}{l}0.963 \\
0.960\end{array}$ \\
\hline $\begin{array}{l}\text { Cavalier } \\
\text { attitudes } \\
\text { towards safety }\end{array}$ & $\begin{array}{l}\text { Seven-point scale from } 1 \text { (never) to } 7 \text { (very often) } \\
\text { - I can do the job safely without following safety procedures. } \\
\text { - I ignore some safety procedures if I am trying to save time. } \\
\text { - The safety procedures do not seem necessary. }\end{array}$ & $\begin{array}{l}2.332 \\
2.126 \\
1.939\end{array}$ & $\begin{array}{l}2.809 \\
2.683 \\
2.623\end{array}$ & $\begin{array}{l}0.792 \\
0.910 \\
0.867\end{array}$ \\
\hline Safety efficacy & $\begin{array}{l}\text { Seven-point scale from } 1 \text { (strongly disagree) to } 7 \text { (strongly agree) } \\
\text { - I am skilled at avoiding the dangers of work place hazards. } \\
\text { - I lam very active in removing work place safety and health hazards. } \\
\text { - I am confident in my ability to remove work place safety and health hazards. }\end{array}$ & $\begin{array}{l}5.169 \\
5.165 \\
4.993 \\
\end{array}$ & $\begin{array}{l}2.826 \\
2.765 \\
2.813 \\
\end{array}$ & $\begin{array}{l}0.898 \\
0.930 \\
0.881\end{array}$ \\
\hline Pressure & $\begin{array}{l}\text { Seven-point scale from } 1 \text { (never) to } 7 \text { (very often) } \\
\text { - I take safety shortcuts when I feel pressure to work fast. } \\
\text { - It is difficult to do a task while following all of the safety rules. } \\
\text { - } \quad \text { My supervisor encourages shortcuts in safety procedures. }\end{array}$ & $\begin{array}{l}3.292 \\
2.791 \\
2.866\end{array}$ & $\begin{array}{l}3.208 \\
3.023 \\
3.178\end{array}$ & $\begin{array}{l}0.842 \\
0.873 \\
0.807\end{array}$ \\
\hline Safety climate & $\begin{array}{l}\text { Seven-point scale from } 1 \text { (strongly disagree) to } 7 \text { (strongly agree) } \\
\text { - I feel comfortable reporting safety or health hazards to my immediate supervisor. } \\
\text { - I feel comfortable reporting work injuries or health effects to my immediate supervisor. } \\
\text { - My immediate supervisor believes work place safety and health are very important. } \\
\text { - My immediate supervisor is a good resource for helping me to solve safety and health problems. } \\
\text { - My immediate supervisor values my ideas about improving safety and health. } \\
\text { - Top management believes work place safety and health are very important. } \\
\text { - The union/company safety committee is effective in improving workplace safety and health. } \\
\text { - The company is concerned about my safety and health when I am away from work. } \\
\text { - } \quad \text { Overall, this is a safe place to work. }\end{array}$ & $\begin{array}{l}4.599 \\
4.724 \\
5.408 \\
5.150 \\
5.523 \\
5.771 \\
5.507 \\
4.827 \\
5.514 \\
\end{array}$ & $\begin{array}{l}3.159 \\
3.125 \\
3.039 \\
3.087 \\
2.782 \\
2.635 \\
2.628 \\
2.952 \\
2.722 \\
\end{array}$ & $\begin{array}{l}0.606 \\
0.598 \\
0.626 \\
0.665 \\
0.768 \\
0.789 \\
0.827 \\
0.750 \\
0.808 \\
\end{array}$ \\
\hline $\begin{array}{l}\text { Employees } \\
\text { experience } \\
\text { with safety and } \\
\text { health } \\
\text { problems }\end{array}$ & $\begin{array}{l}\text { Seven-point scale from } 1 \text { (never) to } 7 \text { (very often) } \\
\text { - I have often seen work related accidents. } \\
\text { - Some of my colleagues have had work related health problems. } \\
\text { - I have experienced a work related accident on my own body. } \\
\text { - I have turned ill due to things that I did at my work. }\end{array}$ & $\begin{array}{l}2.565 \\
2.106 \\
1.508 \\
1.459\end{array}$ & $\begin{array}{l}2.450 \\
2.555 \\
2.182 \\
2.133\end{array}$ & $\begin{array}{l}0.728 \\
0.788 \\
0.701 \\
0.677\end{array}$ \\
\hline $\begin{array}{l}\text { Employees } \\
\text { knowledge of } \\
\text { the factory }\end{array}$ & $\begin{array}{l}\text { Seven-point scale from } 1 \text { (strongly disagree) to } 7 \text { (strongly agree) } \\
\text { - I know the products that the factory where I work produce. } \\
\text { - I know how the factory where I work is organized. } \\
\text { - I know the goals and objectives of the factory where I work. }\end{array}$ & $\begin{array}{l}5.642 \\
5.246 \\
4.964\end{array}$ & $\begin{array}{l}2.703 \\
2.732 \\
2.968\end{array}$ & $\begin{array}{l}0.842 \\
0.821 \\
0.853\end{array}$ \\
\hline
\end{tabular}




\begin{tabular}{|c|c|c|c|c|}
\hline & - I know most of the customers of the factory where I work. & 4.468 & 3.084 & 0.817 \\
\hline Construct & $\begin{array}{ll}\text { Descriptions (scales) of items } \\
\end{array}$ & Mean & S.D. & Loading \\
\hline \multirow{8}{*}{ Safety hazards } & $\begin{array}{l}\text { Back hazards ( } \alpha=0.919, \text { AVE }=0.754, C R=0.939 \text { ) } \\
\text { - I stand for long periods of time. } \\
\text { - Work surface heights are incorrect. } \\
\text { - I work in physically awkward positions. } \\
\text { - I lift objects that are too heavy. } \\
\text { - I lift objects that are too bulky or large. }\end{array}$ & $\begin{array}{l}6.047 \\
6.121 \\
6.360 \\
5.921 \\
6.051\end{array}$ & $\begin{array}{l}4.513 \\
4.286 \\
4.381 \\
4.369 \\
4.120\end{array}$ & $\begin{array}{l}0.731 \\
0.779 \\
0.735 \\
0.721 \\
0.736\end{array}$ \\
\hline & $\begin{array}{l}\text { Industrial hygiene hazards ( } \alpha=0.928, A V E=0.822, C R=0.948 \text { ) } \\
\text { - I work near electrical current. } \\
\text { - I am exposed to toxic chemicals. } \\
\text { - I am exposed to toxic gas. } \\
\text { - I am exposed to radiation. }\end{array}$ & $\begin{array}{l}6.150 \\
6.572 \\
6.561 \\
6.736\end{array}$ & $\begin{array}{l}4.302 \\
4.400 \\
4.411 \\
4.390\end{array}$ & $\begin{array}{l}0.784 \\
0.819 \\
0.825 \\
0.771\end{array}$ \\
\hline & $\begin{array}{l}\text { Sitting hazards ( } \alpha=0.835, \text { AVE }=0.751, C R=0.900 \text { ) } \\
\text { I sit in the same place for long periods of time. } \\
\text { - My chain is uncomfortable. } \\
\text { - My chair is not sturdy }\end{array}$ & $\begin{array}{l}6.112 \\
5.668 \\
5.792\end{array}$ & $\begin{array}{l}4.247 \\
4.259 \\
4.038\end{array}$ & $\begin{array}{l}0.554 \\
0.702 \\
0.785\end{array}$ \\
\hline & $\begin{array}{l}\text { Floor surface hazards ( } \alpha=0.919, \text { AVE=0.861, CR=0.949) } \\
\text { - Work areas are cluttered. } \\
\text { - There are liquid spills on the floor. } \\
\text { - The floor is slippery. }\end{array}$ & $\begin{array}{l}5.951 \\
6.157 \\
6.572 \\
\end{array}$ & $\begin{array}{l}4.098 \\
4.145 \\
4.329\end{array}$ & $\begin{array}{l}0.832 \\
0.840 \\
0.841\end{array}$ \\
\hline & $\begin{array}{l}\text { Air condition hazards ( } \alpha=\mathbf{0 . 8 9 8 ,} \text { AVE= } \mathbf{0 . 8 2 9 ,} \mathrm{CR}=\mathbf{0 . 9 3 6 )} \\
\text { - Room temperatures are too hot. } \\
\text { - Room temperatures are too cold. } \\
\text { - Room air is too humid or damp. }\end{array}$ & $\begin{array}{l}6.668 \\
5.951 \\
6.290\end{array}$ & $\begin{array}{l}4.470 \\
4.077 \\
4.058\end{array}$ & $\begin{array}{l}0.810 \\
0.818 \\
0.832\end{array}$ \\
\hline & $\begin{array}{l}\text { Workplace lighting hazards }(\alpha=0.905, \text { AVE }=0.840, C R=0.940) \\
\text { - There is not enough light where I work. } \\
\text { - There is glare from work surfaces. } \\
\text { - The light in the work area flicker on and off. }\end{array}$ & $\begin{array}{l}6.129 \\
6.374 \\
5.871\end{array}$ & $\begin{array}{l}4.147 \\
4.121 \\
4.039\end{array}$ & $\begin{array}{l}0.819 \\
0.826 \\
0.788\end{array}$ \\
\hline & $\begin{array}{l}\text { Material hazards ( } \alpha=0.918, \text { AVE }=0.859, C R=0.948 \text { ) } \\
\text { - There are sharp edges on work materials. } \\
\text { - There is glare from work materials. } \\
\text { - I work with or near high temperature materials }\end{array}$ & $\begin{array}{l}6.488 \\
6.075 \\
6.159\end{array}$ & $\begin{array}{l}4.163 \\
4.117 \\
4.080\end{array}$ & $\begin{array}{l}0.790 \\
0.794 \\
0.796\end{array}$ \\
\hline & $\begin{array}{l}\text { Equipment unavailability hazards ( } \alpha=0.940, A V E=0.847, C R=0.957) \\
\text { - Safety equipment is not within easy reach. } \\
\text { - Safety equipment does not work very well. } \\
\text { - Tools or equipment do not work the way they should. } \\
\text { - I do not have the correct tool for the job. }\end{array}$ & $\begin{array}{l}5.404 \\
6.215 \\
6.299 \\
6.194\end{array}$ & $\begin{array}{l}3.974 \\
4.106 \\
4.191 \\
4.169\end{array}$ & $\begin{array}{l}0.759 \\
0.818 \\
0.810 \\
0.790\end{array}$ \\
\hline
\end{tabular}




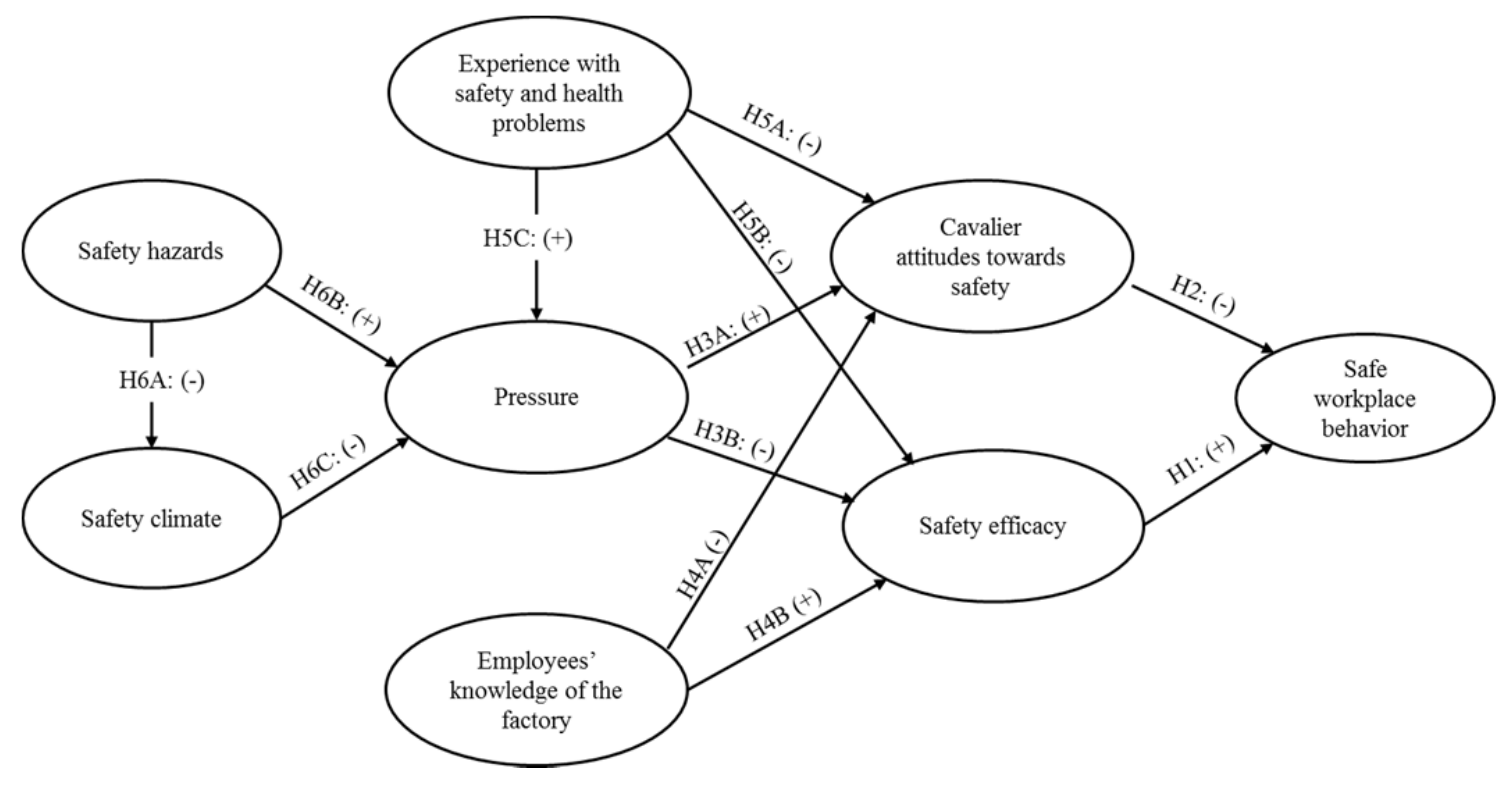

Figure 1. Hypothesised research model.

Table 1. Sample profiles $(n=428)$.

\begin{tabular}{|l|l|c|c|}
\hline Classification & & No. of respondents & $\mathbf{\%}$ \\
\hline Gender & Female & 210 & $49.1 \%$ \\
\hline & Male & 218 & $50.9 \%$ \\
\hline & Total & 428 & $100 \%$ \\
\hline Age & Less than 18 years & 1 & $0.2 \%$ \\
\hline & $19-20$ years & 66 & $15.4 \%$ \\
\hline & $21-25$ years & 176 & $41.1 \%$ \\
\hline & $26-30$ years & 93 & $21.7 \%$ \\
\hline & $31-35$ years & 52 & $12.1 \%$ \\
\hline & $36-40$ years & 28 & $6.5 \%$ \\
\hline & More than 40 years & 12 & $2.8 \%$ \\
\hline & Total & 428 & $100 \%$ \\
\hline
\end{tabular}


Table 2. Reliability and Discriminant Validity

\begin{tabular}{|c|c|c|c|c|c|c|c|c|c|c|c|}
\hline Construct & AVE & CR & $\begin{array}{c}\text { Cronbach's } \\
\text { alpha }\end{array}$ & 1 & 2 & 3 & 4 & 5 & 6 & 7 & 8 \\
\hline 1. Cavalier attitudes towards safety & 0.736 & 0.893 & 0.819 & 0.858 & & & & & & & \\
\hline 2. Employees knowledge of the factory & 0.695 & 0.901 & 0.854 & -0.243 & 0.833 & & & & & & \\
\hline 3. Experience with safety and health problems & 0.525 & 0.815 & 0.699 & 0.170 & -0.265 & 0.725 & & & & & \\
\hline 4. Safety climate & 0.519 & 0.905 & 0.896 & -0.320 & 0.406 & -0.345 & 0.720 & & & & \\
\hline 5. $\quad$ Pressure & 0.707 & 0.879 & 0.801 & 0.475 & -0.178 & 0.107 & -0.214 & 0.841 & & & \\
\hline 6. Safe workplace behavior & 0.925 & 0.961 & 0.919 & -0.314 & 0.291 & -0.169 & 0.489 & -0.275 & 0.962 & & \\
\hline 7. Safety Hazards & 0.615 & 0.978 & 0.977 & 0.252 & -0.141 & 0.096 & -0.157 & 0.354 & -0.225 & 0.784 & \\
\hline 8. Safety efficacy & 0.816 & 0.930 & 0.887 & -0.297 & 0.416 & -0.232 & 0.678 & -0.211 & 0.363 & -0.221 & 0.903 \\
\hline
\end{tabular}


Table 3. Results of hypotheses tests using PLS-SEM.

\begin{tabular}{|c|c|c|c|c|c|}
\hline & Pathways & $\begin{array}{c}\text { Path } \\
\text { Coefficient }\end{array}$ & t-value & p-value & Outcome \\
\hline $\mathrm{H} 1$ & Safety efficacy -> Safe workplace behavior & 0.296 & 5.005 & 0.000 & Supported \\
\hline $\mathrm{H} 2$ & Cavalier attitudes towards safety $->$ Safe workplace behavior & -0.226 & 3.204 & 0.001 & Supported \\
\hline $\mathrm{H} 3 \mathrm{~A}$ & Pressure -> Cavalier attitudes towards safety & 0.441 & 7.697 & 0.000 & Supported \\
\hline $\mathrm{H} 3 \mathrm{~B}$ & Pressure -> Safety efficacy & -0.134 & 2.007 & 0.045 & Supported \\
\hline $\mathrm{H} 4 \mathrm{~A}$ & Employees knowledge of the factory -> Cavalier attitudes towards safety & -0.141 & 2.383 & 0.017 & Supported \\
\hline H4B & Employees knowledge of the factory -> Safety efficacy & 0.360 & 5.624 & 0.000 & Supported \\
\hline H5A & Experience with safety and health problems -> Cavalier attitudes towards safety & 0.085 & 1.176 & 0.240 & Not supported \\
\hline H5B & Experience with safety and health problems -> Safety efficacy & -0.122 & 1.898 & 0.058 & Supported \\
\hline $\mathrm{H} 5 \mathrm{C}$ & Experience with safety and health problems $->$ Pressure & 0.022 & 0.344 & 0.731 & Not supported \\
\hline H6A & Safety Hazards -> Safety climate & -0.157 & 2.005 & 0.045 & Supported \\
\hline H6B & Safety Hazards -> Pressure & 0.328 & 6.032 & 0.000 & Supported \\
\hline $\mathrm{H} 6 \mathrm{C}$ & Safety climate -> Pressure & -0.155 & 2.394 & 0.017 & Supported \\
\hline
\end{tabular}




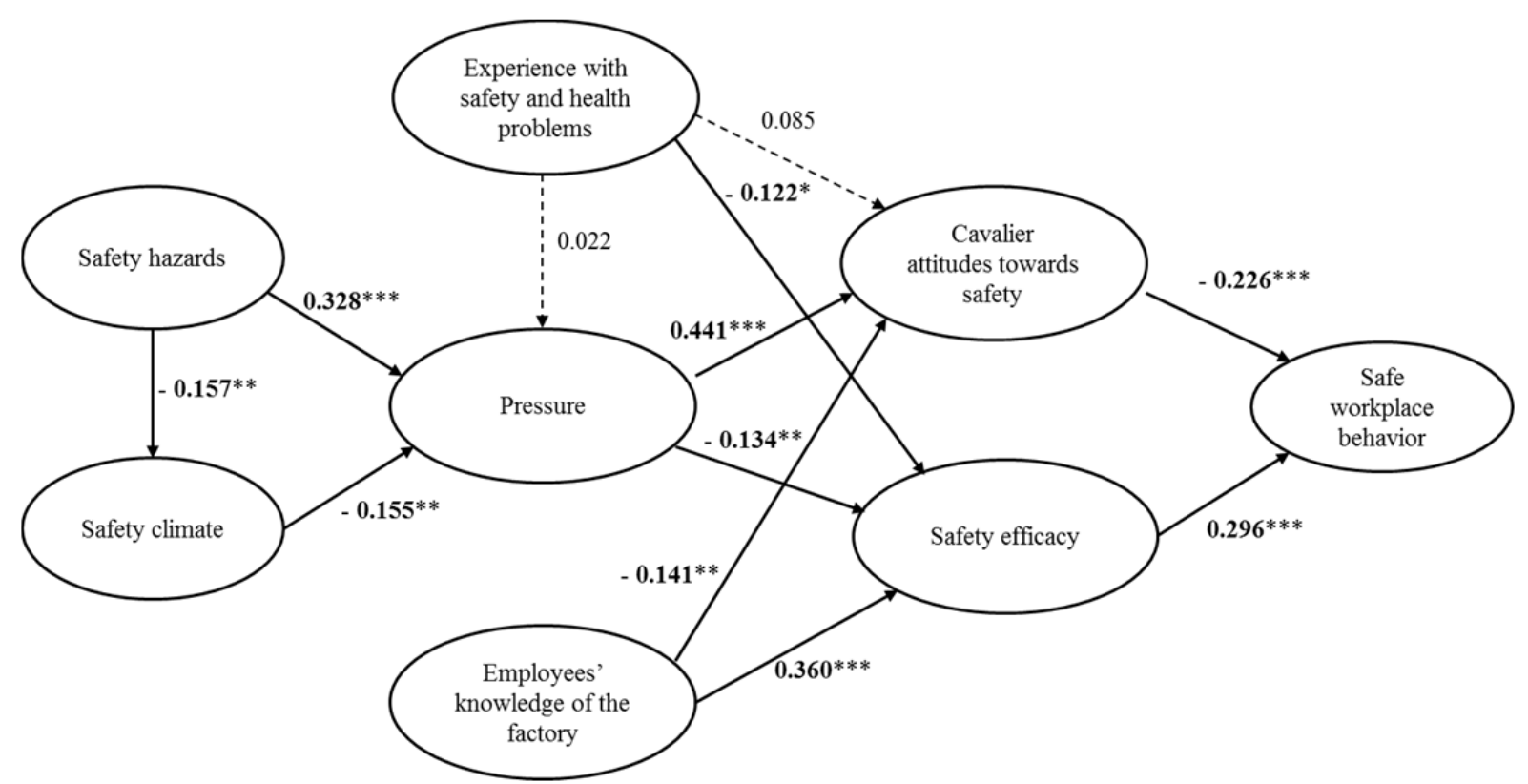

Figure 2. Path model analyses. Significant path coefficients are highlighted in bold.

* Significance at 0.10 level; ** significance at 0.05 level; *** significance at 0.01 level. 